\title{
Analysis of Performance Appraisal System of the Daphne Company Based on KPI
}

\author{
Yanni Yao ${ }^{1} \&$ Yingying $\mathrm{Li}^{1}$ \\ ${ }^{1}$ Management faculties of graduate students, Shanghai University of Engineering Science, Shanghai, China \\ Correspondence: Yanni Yao, San Xin North road No.1800 20th floor, Room 5013, Songjiang, Shanghai, China. Tel: \\ 86-150-0017-1162. E-mail: 15956976431@163.com
}

Received: April 28, $2014 \quad$ Accepted: May 12, $2014 \quad$ Online Published: June 4, 2014

doi:10.5430/sass.v1n2p84 URL: http://dx.doi.org/10.5430/sass.v1n2p84

\begin{abstract}
Performance appraisal is an important part of enterprise's human resource management. It can provide an important basis for the salary adjustments of employees, job promotion and training development. This thesis is starting from the status of analysis of Daphne's performance appraisal, adopting Key Performance Indictor performance appraisal in human resources management model, to analyze Daphne's problems of performance appraisal. With the practical situation of the theory of knowledge combined with Daphne, the thesis aim at designing a full set of performance appraisal system. In the process of establishing the system, the first is to introduce the performance appraisal system which is applied to the theoretical overview; Secondly, we describe how to use key performance to analyze Daphne's performance appraisal system after some introductions of relevant concepts of performance appraisal; Finally, as an example in HR positions, setting Key Performance Indicator's do a more detailed set of indicators sample.
\end{abstract}

Keyword: Performance appraisal, Key Performance Indicators (KPI), Daphne’s performance appraisal system

\section{Daphne's Performance Appraisal and Management Status}

As a mature enterprise, Daphne's market is relatively stable.In addition to a breakthrough in the strategic planning for greater development, it also in the management to innovate, change, use of advanced, scientific management, to meet the needs of the enterprise development strategy. This paper is from the perspective of human resource management system of performance management, to design a set of perfect appraisal system for Daphne, in order to provide help to the enterprise management.

\subsection{The Current Performance Appraisal System}

The company has established the branch manager of KPI appraisal system and front-line staff appraisal system, but headquarters managers and employees have no evaluation index.

\subsubsection{Branch Manager Evaluation}

The branch manager is to implement annual comprehensive examination, which mainly includes 3 assessment indexes: Sales completion rate, profit rate, opening rate reached. These 3 indicators have different weight ratio, according to the 3 indexes reached the accounting year bonus. As the following table 1:

Table 1. Daphne branch manager performance evaluation table

\begin{tabular}{|l|l|l|l|l|}
\hline KPI & Index & Weights & Actual completion & Achievement rate \\
\hline Sales & 2 One hundred million & $60 \%$ & 1.8 One hundred million & \\
\hline Profits & 0.8 One hundred million & $20 \%$ & 0.5 One hundred million & \\
\hline Shop number & 20 & $20 \%$ & 20 & \\
\hline & $\begin{array}{l}\text { Bonus }=\text { The total prize money } \text { Sales reached a rate·Profit rate reached } \text { Shop achievement rate } \\
\text { Remark: Award amounts up to 2 times the performance of the contract bonuses }\end{array}$ \\
\hline
\end{tabular}


Before the branch manager signs annual performance contracts with headquarters, the two sides will communicate to discuss on the three indicators of target and prize money. After the two sides reach consensus, they will sign up performance contracts for next year. In assessment implementation process, branch managers will do debriefing report to the headquarters quarterly, with operations and finance departments providing quarterly data.

\subsubsection{Assessment Managers and General Staff Headquarters}

There are no assessment indicators for headquarters managers and ordinary employees, but at the end of a temporary set of several professional quality projects, directly subordinate to the scoring by the department head, according to the number of mandatory standard normal distribution, named excellent, good, in, passing, unqualified 5 levels. After the head of the evaluation, the year-end outstanding employees can take a month-salary-bonus.Good employees can get $80 \%$ bonus of one month salary, medium employees can get $50 \%$ bonus of one month salary, the other employees do not, fail employees take discouraging way.

\subsection{Analysis of Current Situation of Performance Appraisal}

From the current situation of Daphne assessment, we can see that, in addition to branch managers and front-line sales personnels, performance evaluation for functional department is almost empty, however branch manager of the performance index also focused on data relating to the sale, without professionalism and competency assessment indicators. Single sales assessment indicators guide the branch manager to focus more on results, then ignore the training of personnel, and also neglect the qualities of cultivating excellent teams and personnels which should be qualified as a good professional manager.

Daphne's personnel structure presents a clear differentiation: a part of the staff is very stable, whose seniority over 7-8 years. This part of the staff of the Daphne has a good sense of belonging; other staff positions is very unstable, often recruit people, but do not always stay living provoke talents. The result of this polarization is: the experienced staff lack passion, pioneering spirit, and a sense of competition;for the new employees,they cannot see a clear goals, have no motivation and sense of belonging.Imagine going for long time, creative talents cannot be kept, therefore enterprise will be lack of fresh blood and vitality, lack of knowledge and management updates. So, how can it develop for long time?

\section{Performance Appraisal Related Concepts Outlined}

Performance, means effectiveness and efficiency of the people who have reached a certain quality requirements through compliance with organizational behavior. Performance includes both organizational performance and individual performance levels, where organizational performance is the result of the final operational management of the organization, and individual performance is the result of the individual to perform their duties in accordance with the agreed business rules.

Performance management refers to a kind of management activities which is through the establishment of corporate strategy, target decomposition, performance evaluation, and performance results for the daily management of the activities of the enterprise in order to motivate employee performance and, ultimately, to achieve continuous improvement and objectives of an organization's strategic management.

The process of performance management is often seen as a cycle, which is divided into four areas, namely: performance planning, performance coaching, performance appraisal and performance feedback.

Performance appraisal refers to a process of the evaluation of the main control objectives or performance criteria, using scientific evaluation methods to assess the employee's work tasks completed, the job responsibilities of employees and staff to fulfill the degree of development, and the results will be fed back to assessing employees.

Performance appraisal is a part of the cycle of performance management, whose quality and efficiency of performance appraisal, will impose a decisive impact on the entire performance management activities. Performance appraisal aims to achieve two purposes: the first is performance improvement, the second is the value of the evaluation. Assessment for performance improvement and a focus on improving methods to solve the problem, in order to achieve improved performance.

The most important thing of performance management is to let employees know what the company requires of him, and how he will work to improve the work; What KPI must be clearly in charge of his company's requirements, the requirements of his department, that department is to understand, while competent to understand the quality of the staff, so that targeted distribution of work and setting goals.Through KPI's discussions, through communication, clear departmental goals and objectives of the consistency of the staff. 
In the course manager constant communication with subordinates, counseling and help keep subordinates, recording operating data or factual basis for the staff, to ensure consistency in achieving its goals, it is more important than the assessment itself.

Evaluate employee's performance improvements, and performance results, KPI is a fundamental basis. It provides an assessment of the direction of the data and facts.

Assessment is not an objective, but the means of incentives to promote performance improvement and increase the real purpose of improving the quality and capability of staff is.

\section{Key Performance Indicators (KPI)}

\subsection{The Definition of $K P I^{\prime}$}

KPI refers to key indicators of qualifying the effects of a corporate's strategy, that is setting the key parameters of corporate's interior, breaking down organization's strategic objectives into a tool as operational vision objectives.It is the basis for enterprise performance management system. Its purpose is to establish a mechanism to corporate strategy into internal processes and activities so as to continuously enhance the core competitive- ness of enterprises and access to sustainable development. So you can implement the strategic go- als and business emphasis through KPI, and pass the company's value-orientation, effectively motivate employees, increase in per capita efficiency, promote the company and employee performance improvement and enhancement.

\subsection{The Features of KPI}

Decomposition of the company's strategic goals: The company's strategic objective is long-term, guiding and general, thus every position's key performance indicators, and are rich in contents.It is measurable because it focuses on performance appraisal of that year. Therefore, the key performance indicators are the real drivers of specific factors to achieve the company's strategic objectives excavations; it is a concrete manifestation of the company's strategy for each post job performance requirements.

The key business activities to measure: Work content of each post are related to different aspects of the work of senior management. This task is more complex, but KPI for the company's overall strategic objectives which greater impact only on. Plays an integral role to achieve the strategic objectives of the work carried out to measure.

KPI be recognized organization from top to bottom: KPI is not determined by a superior force under the hair, nor formulate by their own positions, but by superiors and employees to participate in the completion of the development, which is a manifestation of a consensus reached by the two sides. It is not the tool of pressing the low, but a common recognition for organization's relevant personnels of position's requirements of job performance.

\subsection{KPI Should Follow the Principles of Design}

\subsubsection{Establish the basic principles to be followed KPI}

First, goal-oriented, that is KPI is decided by enterprise's goals, departmental goals and positional objectives.

Second, pay attention to the quality of work.The quality of work is the core competitiveness of enterprises, but it is difficult to measure. Therefore, it is necessary to establish indicators to control the quality of work.

Third, operability. KPI indicators must ensure operability technically. For each indicator, it must give a clear definition, and establish a sound channels of collecting information. At the same time, it should be simple, easy to understand and be accepted by the debtor.

Fourth, the balance of the target. Targets, which are related to cooperation of relevant departments and mutual support will be made jointly by relevant departments' combined processes. Of course, many indicators are relevant, or cross, or overlap, or antagonistic. Index lies not in comprehensive, scientific, but rather focused and effective.

Fifth, with the control. KPI assessment were to be reached to deal with considerable control. When setting objectives and performance appraisal whether the post office can control the results of the index should be taken into consideration, if the incumbent can not control, the index can not be used as a measure of the incumbent's performance standard.

\subsubsection{Follow the SMART Principles}

First, KPI must be specific, mainly referring to the target refinement can be changed with the situation;

Second, KPI must be measurable, which means that the target should be able to quantify the degree or behavior of; 
Third, KPI must be achieved, which is the goal formulated neither high nor low, moderate and can be achieved within the time limit;

Fourth, KPI must be realistic, which refers that objective results can be observed or proved;

Fifth, KPI must be a time limit, which is mentioned makers to focus on efficiency.

\subsection{The Significance of KPI}

Help to implement corporate strategy: The implementation of strategic objectives necessarily be put on every person through the organizational system. Through playing the role of personnels' effects, it can realize the establishment of objective performance indicator system, to make the organization's indicators clear, specific and quantified. By passing from top to bottom so that the company's strategic goal is not just high-level objectives more closely related to each department for each job task.

Helps companies coordinated various departments: By expliciting several key and overall coordinated quantitative indicators, put all departments and positions of company into both division of labor and cooperation, according to departments job responsibilities of each position, to efficiently guarantee the achievement of the company's strategic objectives.

Enhance the company's ability of forecasting and early-warning: According to key qualified performance indicators data, managers can be greatly enhanced of the ability to predict future performance. While quantitative indicators data can help companies understand their current situation as soon as possible, it provides an important basis for the company to change management decisions.

Help to improve the management level and skills of managers: Enables managers to effectively understand the corporate strategic objectives, so that better take action in the areas of their jurisdiction. Coupled with the performance indicator system emphasizes maintains that reasonable goal for target analysis, evaluation, tracking and improvement, it helps to improve levels of managers management level.

\subsection{The Design Methods of KPI}

The major steps of "fishbone diagram" analysis: Fishbone diagram is a discovery issue "root cause" approach, which originally mainly used for quality management, and is now applied to the analysis of key performance indicators designed primarily as follows:

(1) To determine the individual and departmental business priorities and what factors affect the business of the organization.

(2) Determine the operational standards, key elements of the definition of success, to meet strategic business focus means required.

(3) Identification of key performance indicators to determine whether a particular performance standards in line with the actual situation. The organization-level KPI gradually broken down to departments, and then decomposed by the department to various positions, followed by the use of layers of decomposition, mutually supportive approach to determine the various departments, key performance indicators for each job, and determined by a quantitative or qualitative indicators.

The major steps of "JiuGongTu" analysis: Create a two-dimensional coordinates, respectively, of three parallel lines equally in the abscissa and ordinate of the two-dimensional coordinates, which is formed of six parallel lines cross nine squares. This nine squares called "JiuGongTu."

(1) Department business focus as abscissa, personal business focus as ordinate.

(2) Determine the success of the business sector and individual key elements, namely to identify the influence of the size of business success are arranged in a grid.

(3) Identify key business indicators, trends from the coordinate grid can be judged.

KPI based on key performance factors affecting the level of success factors, and thus will be listed in descending layers of decomposition, and describe a quantitative or qualitative indicators.

\subsection{The Extraction of KPI}

\subsubsection{Strategic Objectives "Fishbone Diagram" Decomposition and KPI Extraction}

Overall strategic objectives of the organization in general, can be broken down into several main objectives to support sub-objectives, and then these sub-objectives are broken down into more specific goals, that is "Sun" goal. 
The organization itself needs the support of some of the key business processes in order to reach a certain extent, and KPI indicators can be decomposed out of business processes. Therefore, in this part, the following tasks are needed to complete:

(1) Top of the organization need to establish the overall strategic objectives of the organization.

(2) By the organization's overall strategic objectives will rise as the main support for the decomposition temper goal.

(3) Establish a link between the organization's key business processes and support temper goals.

(4) In the main business processes in the enterprise, and then break out the KPI.

\subsection{2 "JiuGongTu" Confirm Links between Business Processes and the Various Functional Departments}

Through "JiuGongTu" way, establish association between related processes and job functions, and thus is establish the relationship within processes, functions and indicators in a more micro level, aiming to establish contacts between the organization's overall strategic objectives and sectored performance indicators. Know the relationship between the various work processes and functions of the various departments after the assessment indicators can be linked with business processes, and thus support the patience to achieve goals; ultimately through microscopic performance index, especially key performance indicators to achieve the organization's overall strategic objectives.

\subsubsection{Extraction Departmental KPI Indicators}

In this session, you can extract departmental KPI targets from the links between business processes and departmental responsibilities which are set up in the above sessions.

\subsubsection{Unity of Purpose, Processes, Functions and Job Goals}

According to department KPI, business processes and the determined responsibilities of each position, establish an unification of organizational goals, processes, functions and positions, and make it clear of the link between job responsibilities and organizational goals.

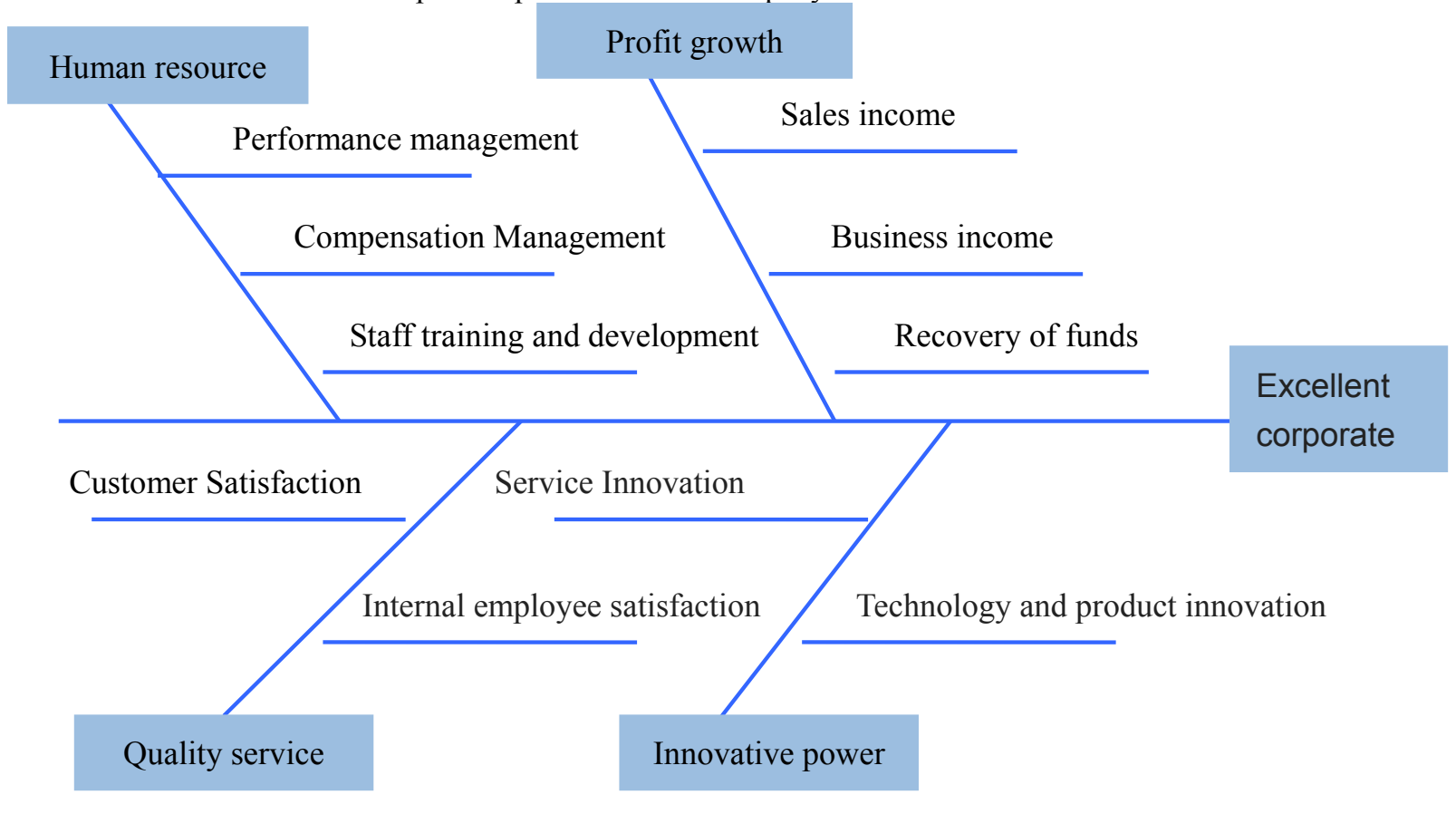

Figure 1.

\section{Examples of KPI Extraction of Daphne}

\subsection{Sector / Branch Performance Indicators}

According to the steps described in the foregoing decomposition of business goals and the introduction of tools used, 
combined with Daphne strategic management objectives, it decomposes into key indicators of managers of the company, as well as the heavy weight of each item index, calculated / measurable way, the data provider.

Table 2. Daphne branch KPI example table

\begin{tabular}{|c|c|c|c|c|}
\hline Indicator Type & KPI & $\begin{array}{l}\text { Weight } \\
\mathrm{s}\end{array}$ & $\begin{array}{l}\text { Calculation or measurement } \\
\text { methods }\end{array}$ & Data Sources \\
\hline \multirow{3}{*}{ Finance } & Profit per & $15 \%$ & $\begin{array}{l}\text { Net profit / total number (Group } \\
\text { headquarters and branches) }\end{array}$ & Finance / Human \\
\hline & $\begin{array}{l}\text { Headquarters costs control } \\
\text { rate }\end{array}$ & $5 \%$ & $\begin{array}{l}\text { Actual costs / budget expenses } \\
\text { (Headquarters) }\end{array}$ & Finance \\
\hline & Group profit contribution rate & $5 \%$ & $\begin{array}{l}\text { A total profit of (sub) Company } \\
\text { / Group gross profit }\end{array}$ & Finance \\
\hline \multirow[b]{2}{*}{ Customer } & $\begin{array}{l}\text { Internal } \\
\text { Satisfaction }\end{array}$ & $10 \%$ & $\begin{array}{l}\text { Internal Customer Satisfaction } \\
\text { Survey }\end{array}$ & $\begin{array}{l}\text { Manager's Office, } \\
\text { Human }\end{array}$ \\
\hline & Resolve complaints rate & $10 \%$ & $\begin{array}{l}\text { The number of complaints } \\
\text { resolved / total number of } \\
\text { complaints }\end{array}$ & $\begin{array}{l}\text { Records of } \\
\text { complaints and } \\
\text { resolution records }\end{array}$ \\
\hline \multirow{5}{*}{$\begin{array}{l}\text { Processes and } \\
\text { core } \\
\text { responsibilities }\end{array}$} & $\begin{array}{l}\text { Training program completion } \\
\text { rate }\end{array}$ & $9 \%$ & $\begin{array}{l}\text { Number of items in a timely } \\
\text { training, training program } \\
\text { number (headquarters) Project }\end{array}$ & $\begin{array}{l}\text { Manager's } \\
\text { Human }\end{array}$ \\
\hline & $\begin{array}{l}\text { Headquarters } \\
\text { satisfaction }\end{array}$ & $9 \%$ & $\begin{array}{ll}\text { Headquarters } & \text { Employee } \\
\text { Satisfaction Survey } & \\
\end{array}$ & $\begin{array}{l}\text { Manager's } \\
\text { Human }\end{array}$ \\
\hline & Key personnel turnover rate & $9 \%$ & $\begin{array}{l}\text { Total number of key talent } \\
\text { critical loss of talent within a } \\
\text { certain period / company }\end{array}$ & $\begin{array}{l}\text { Manager's } \\
\text { Human }\end{array}$ \\
\hline & Jobs timely key rate & $9 \%$ & $\begin{array}{l}\text { Recruitment several key } \\
\text { positions in a timely manner/the } \\
\text { total number of plans to recruit } \\
\text { key positions }\end{array}$ & $\begin{array}{l}\text { Manager's } \\
\text { Human }\end{array}$ \\
\hline & Recruitment pass rate & $9 \%$ & $\begin{array}{l}\text { The number of new employees } \\
\text { through a trial period / total } \\
\text { number of recruitment } \\
\text { (Headquarters) }\end{array}$ & $\begin{array}{l}\text { Manager's } \\
\text { Human }\end{array}$ \\
\hline \multirow{2}{*}{$\begin{array}{l}\text { Ability and } \\
\text { Development }\end{array}$} & $\begin{array}{l}\text { Department } \\
\text { satisfaction }\end{array}$ & $5 \%$ & $\begin{array}{l}\text { Employee Satisfaction Survey } \\
\text { Department (Department) }\end{array}$ & $\begin{array}{l}\text { Manager's } \\
\text { Human }\end{array}$ \\
\hline & $\begin{array}{l}\text { Enhance the management } \\
\text { level }\end{array}$ & $5 \%$ & $\begin{array}{l}\text { Improve the level of internal } \\
\text { management } \\
\text { (department) }\end{array}$ & $\begin{array}{l}\text { Manager's } \\
\text { Human }\end{array}$ \\
\hline
\end{tabular}

1. Indicator Type:

(1) Financial: to achieve a predetermined profit targets, the ability to control costs:

KPI:

Per capita profit: the ability to create profits per capita, the index can be laterally than with other branches Earlier, reflecting profitability management.

Headquartered cost control rate: ability to execute the budget, personnel costs reflect management control level.

Group profit contribution rate: detection of (sub) company contribution across the company's profits.

(2) Customers: Inter sectoral collaboration, decision-making ability to execute

KPI:

Internal Customer Satisfaction: A questionnaire survey of internal customer satisfaction.

Resolve complaints rate: reflects the emphasis on the customer, and the processing speed of the complaint.

(3) Process and core responsibilities: team building organization, personnel management jobs

KPI: 
Training program completion rate: the implementation of staff training programs, training of that indicator reflects the company's business operations.

Headquarters staff satisfaction: A questionnaire survey of employees of the company culture, leadership and management methods approved circumstances.

Key personnel turnover rate: This indicator provided by the Human Resources Management Department, key personnel turnover rate reflects the level of company cohesion.

Key Jobs timely rate: Nature significant personnel in key positions, directly affect the company's business. The indicator reflects the human resource management capabilities.

Recruit qualified rate: Anti Alba operational capacity of human resources management department.

(4) The ability and development: management sector leaders

KPI:

Department employee satisfaction: through questionnaires, staff-led investigation department of the situation can be led to discover the advantages and disadvantages of work, communicate through this form.

Enhance the management level: sector institutional development, internal control assessment department leadership management capabilities.

\subsection{Performance Indicators for Each Job}

After determining the department's key performance indicators, it need to be broken down into various positions (branch need to break down the various departments and subordinate positions). The following tables are the key performance indicators for each HR positions, weight, unit of account, calculated or measured approach. The number of jobs key performance indicators listed is determined by the number of department' positions.

Table 3. Human Resources Manager jobs K P I example table

\begin{tabular}{|c|c|c|c|c|}
\hline Indicator Type & KPI & $\begin{array}{l}\text { Weigh } \\
\text { ts }\end{array}$ & $\begin{array}{l}\text { Calculation or measurement } \\
\text { methods }\end{array}$ & Data Sources \\
\hline \multirow{3}{*}{ Finance } & Profit per & $5 \%$ & $\begin{array}{l}\text { Net profit / total number (Group } \\
\text { headquarters and branches) }\end{array}$ & Finance / Human \\
\hline & $\begin{array}{l}\text { Headquarters costs } \\
\text { control rate }\end{array}$ & $5 \%$ & $\begin{array}{l}\text { Actual costs / budget expenses } \\
\text { (Headquarters) }\end{array}$ & Finance \\
\hline & $\begin{array}{l}\text { The total labor cost } \\
\text { control rate }\end{array}$ & $5 \%$ & $\begin{array}{l}\text { The actual labor costs / planned } \\
\text { labor costs (department) }\end{array}$ & Finance/Human \\
\hline \multirow[b]{2}{*}{ Customer } & $\begin{array}{ll}\text { Internal } & \text { Customer } \\
\text { Satisfaction } & \end{array}$ & $10 \%$ & $\begin{array}{l}\text { Internal Customer Satisfaction } \\
\text { Survey }\end{array}$ & $\begin{array}{l}\text { Manager's Office, } \\
\text { Human }\end{array}$ \\
\hline & Resolve complaints rate & $10 \%$ & $\begin{array}{l}\text { The number of complaints } \\
\text { resolved / total number of } \\
\text { complaints }\end{array}$ & $\begin{array}{l}\text { Records of } \\
\text { complaints and } \\
\text { resolution records }\end{array}$ \\
\hline \multirow{5}{*}{$\begin{array}{l}\text { Processes and core } \\
\text { responsibilities }\end{array}$} & $\begin{array}{l}\text { Training program } \\
\text { completion rate }\end{array}$ & $10 \%$ & $\begin{array}{l}\text { Number of items in a timely } \\
\text { training, training program } \\
\text { number (headquarters) Project }\end{array}$ & $\begin{array}{l}\text { Manager's Office, } \\
\text { Human }\end{array}$ \\
\hline & $\begin{array}{l}\text { Headquarters } \\
\text { satisfaction }\end{array}$ & $10 \%$ & $\begin{array}{ll}\text { Headquarters } & \text { Employee } \\
\text { Satisfaction Survey } & \end{array}$ & $\begin{array}{l}\text { Manager's Office, } \\
\text { Human }\end{array}$ \\
\hline & Employee turnover rate & $10 \%$ & $\begin{array}{l}\text { Leaving the number / total } \\
\text { number of employees } \\
\text { (department Universal) }\end{array}$ & $\begin{array}{l}\text { Manager's Office, } \\
\text { Human }\end{array}$ \\
\hline & $\begin{array}{l}\text { Completion rates } \\
\text { published in the Journal }\end{array}$ & $10 \%$ & $\begin{array}{l}\text { Timely publication number } \\
\text { plan for note number }()\end{array}$ & $\begin{array}{l}\text { Manager's Office, } \\
\text { Human }\end{array}$ \\
\hline & $\begin{array}{l}\text { Staff organize cultural } \\
\text { events completion rate }\end{array}$ & $10 \%$ & $\begin{array}{l}\text { Views timely organizational } \\
\text { culture events / number of } \\
\text { activities planned cultural }()\end{array}$ & $\begin{array}{l}\text { Manager's Office, } \\
\text { Human }\end{array}$ \\
\hline \multirow{2}{*}{$\begin{array}{l}\text { Ability and } \\
\text { Development }\end{array}$} & $\begin{array}{l}\text { Department employee } \\
\text { satisfaction }\end{array}$ & $5 \%$ & $\begin{array}{l}\text { Employee Satisfaction Survey } \\
\text { Department (Department) }\end{array}$ & $\begin{array}{l}\text { Manager's Office, } \\
\text { Human }\end{array}$ \\
\hline & $\begin{array}{l}\text { Enhance } \\
\text { management level }\end{array}$ & $5 \%$ & $\begin{array}{l}\text { Improve the level of internal } \\
\text { management } \\
\text { (department) }\end{array}$ & $\begin{array}{l}\text { Manager's Office, } \\
\text { Human }\end{array}$ \\
\hline
\end{tabular}


Table 4. HR Employee Relations jobs KPI example table

\begin{tabular}{|c|c|c|c|c|}
\hline Indicator Type & KPI & $\begin{array}{l}\text { Weigh } \\
\text { ts }\end{array}$ & $\begin{array}{l}\text { Calculation or measurement } \\
\text { methods }\end{array}$ & Data Sources \\
\hline Finance & Profit per & $15 \%$ & $\begin{array}{l}\text { Net profit / total number (Group } \\
\text { headquarters and branches) }\end{array}$ & Finance / Human \\
\hline \multirow[b]{2}{*}{ Customer } & $\begin{array}{ll}\text { Internal } & \text { Customer } \\
\text { Satisfaction } & \\
\end{array}$ & $10 \%$ & $\begin{array}{l}\text { Internal Customer Satisfaction } \\
\text { Survey }\end{array}$ & $\begin{array}{l}\text { Manager's Office, } \\
\text { Human }\end{array}$ \\
\hline & Resolve complaints rate & $10 \%$ & $\begin{array}{l}\text { The number of complaints } \\
\text { resolved / total number of } \\
\text { complaints }\end{array}$ & $\begin{array}{l}\text { Records of } \\
\text { complaints and } \\
\text { resolution records }\end{array}$ \\
\hline \multirow{5}{*}{$\begin{array}{l}\text { Processes and core } \\
\text { responsibilities }\end{array}$} & $\begin{array}{l}\text { Training program } \\
\text { completion rate }\end{array}$ & $15 \%$ & $\begin{array}{l}\text { Number of items in a timely } \\
\text { training, training program } \\
\text { number (headquarters) Project }\end{array}$ & $\begin{array}{l}\text { Manager's Office, } \\
\text { Human }\end{array}$ \\
\hline & $\begin{array}{l}\text { Headquarters } \\
\text { satisfaction }\end{array}$ & $10 \%$ & $\begin{array}{ll}\text { Headquarters } & \text { Employee } \\
\text { Satisfaction Survey } & \end{array}$ & $\begin{array}{l}\text { Manager's Office, } \\
\text { Human }\end{array}$ \\
\hline & Employee turnover rate & $10 \%$ & $\begin{array}{l}\text { Leaving the number / total } \\
\text { number of employees } \\
\text { (department Universal) }\end{array}$ & $\begin{array}{l}\text { Manager's Office, } \\
\text { Human }\end{array}$ \\
\hline & $\begin{array}{l}\text { Staff organize cultural } \\
\text { events completion rate }\end{array}$ & $10 \%$ & $\begin{array}{l}\text { Views timely organizational } \\
\text { culture events / number of } \\
\text { activities planned cultural () }\end{array}$ & $\begin{array}{l}\text { Manager's Office, } \\
\text { Human }\end{array}$ \\
\hline & $\begin{array}{l}\text { Completion rates } \\
\text { published in the Journal }\end{array}$ & $10 \%$ & $\begin{array}{l}\text { Timely publication number } \\
\text { plan for note number () }\end{array}$ & $\begin{array}{l}\text { Manager's Office, } \\
\text { Human }\end{array}$ \\
\hline \multirow{2}{*}{$\begin{array}{l}\text { Ability and } \\
\text { Development }\end{array}$} & $\begin{array}{l}\text { Personal qualities and } \\
\text { skills upgrading }\end{array}$ & $5 \%$ & $\begin{array}{lcc}\text { Personal qualities, } & \text { skills } \\
\text { assessment (individual) } & \end{array}$ & Human \\
\hline & $\begin{array}{l}\text { Staff training and } \\
\text { motivation satisfaction }\end{array}$ & $10 \%$ & $\begin{array}{l}\text { With subordinate } \\
\text { satisfaction survey ratings }\end{array}$ & Human \\
\hline
\end{tabular}

These are part of the design Daphne HR performance indicators job done description, performance indicators and other departments can do the same job form.

\section{Conclusion}

Based on key performance indicators reference (KPI) analysis, this article designs a performance appraisal system for Daphne, which makes the company's assessment indicators specific, detailed oriented, so that each department and each job has its specific assessment criteria for performance appraisal. This makes the outcome more favorable performance appraisal to improve the company's operations. Meanwhile, due to the limited theoretical and practical experience, this paper still remains many deficiencies in many aspects. In the coming days, I will continue focusing on research and exploration in this area, struggling for continuous improvement

\section{References}

Bao Ligang. (2012). Application fishbone diagram and JiuGongTu extracted on KPI design. Business management, 6.

Celik Parkan, \& Ming-Lu Wu. (2002). Measuring the performance of operations of HongKong's manufacturing industries. Department of Management Sciences, City University of HongKong, 2002, 6.

Fang Zhenbang, \& Wang guoliang. (2005). With KPI as the core enterprise performance management system design, China Human Resources Development, 1.

Gu Yingwei, \& Li Juan. (2007). Key Performance Indicators. Modern Management Science, 6.

http://baike.so.com./doc/4949848.html

Jiang Qinghua. (2004). How to design performance appraisal functional departments. Copper Project, 2004(03).

Lin Zeyan, \& Wang Jicheng. (2003). Physical performance assessment. Guangdong's economic publication, 2003(1), 119-121.

Liu Anran. Daphne performance management system set up research [Dissertation]. 
Memoir Armada, \& Misreading Dwarf. (1999). Establishing and improving manufacturing performance measures. School of Science and Technology, Manufacturing and Design Press, 1999, 6. pp. 45-77.

Peng Jianfeng. Introduction to Human Resource Management. Fudan University Press.

Rao Zheng, \& Sun Bo. (2003). In the core of performance management KPI. Chinese People University Press.

Robert Bake Wo. (2000). Performance management. Chen Zhouping translation. China Standard Press, 2000, 1, 56-59.

Ruan Yuansheng. (2009). Establish KPI as the core of enterprise performance management. Human Resource Development, 2009(2).

Sun hui, \& Wu jiabao. (2012). How to design KPI. Business management, 3.

Wang xiaomei. (2006). Preliminary evaluation index system based on corporate performance KPI- Aproperty management company to establish performance evaluation indicator systems an example. Tianjin Professional College, 15(2).

Yan Xingyu. Performance management of public community property under the View [Dissertation].

Zhu Weidong. (2012). Key Performance Indicators System Design. Enterprise Reform and Management, 2012(9). 